\title{
Measuring efficiency of Islamic Banks: evidence from Indonesia
}

\author{
Mohamad Fany Alfarisi", Syukri Lukman \\ Faculty of Economics, Universitas Andalas, Padang, Indonesia \\ *E-mail:mfany@eb.unand.ac.id
}

\section{Keywords:}

Efficiency, Islamic banks, Indonesia.

DOI:

$\underline{\text { 10.20885/JEKI.vol5.iss1.art1 }}$

\begin{abstract}
The present study investigates the efficiency of Islamic banks in Indonesia particularly for the period of 2014-2015. To meet that objective, the data envelopment analysis (DEA) particularly input-oriented, variable return to scale (VRS) has been employed. Additionally, twelve fullfledge Islamic commercial banks are included as the sample of the study. Having analysed using the DEA model, we find the average technical efficiency score of Islamic banks in 2014 is 0.843 . In this regard, the inefficiency of Islamic banks is attributed equally to pure technical efficiency and scale efficiency. Moreover, the average technical efficiency score of Islamic banks for the year of 2015 is 0.832 which is lower than the previous year. The inefficiency of Islamic banks in 2015 is mainly contributed by the scale inefficiency. Moreover, the results reveal a declining productivity of Islamic banks during the period of study.
\end{abstract}

\begin{abstract}
Abstrak
Penelitian ini menguji efisiensi Bank Syariah di Indonesia selama periode tahun 2014-2015. Untuk mencapai tujuan tersebut digunakan data envelopment analysis (DEA) kususnya inputoriented, dengan menggunakan variable return to scale (VRS). Sample yang digunakan adalah 12 bank syariah. Dengan menggunakan model analisis DEA, penulis menemukan nilai efisiensi teknis rata-rata di tahun 2014 sebesar 0.843. dalam hal ini, ketidakefisienan bank syariah dikaitkan dengan efisiensi teknis murni dan efisiensi skala. Apalagi skor efisiensi teknis rata-rata bank syariah untuk tahun 2015 adalah 0,832 yang lebih rendah dari tahun sebelumnya. Inefisiensi bank syariah pada tahun 2015 terutama disumbang oleh skala inefisiensi. Selain itu, hasilnya menunjukkan penurunan produktivitas bank syariah selama periode penelitian.
\end{abstract}

\section{Introduction}

Islamic banking industry in Indonesia has gone through challenging episodes in the last four years. The statistic released by the Indonesia Financial Services Authority or also known as Otoritas Jasa Keuangan (OJK) suggests a number of bank-specific indicators namely capital adequacy ratio (CAR), return on assets (ROA), return on equity (ROE) and financing to deposits ratio have declined substantially. However, other indicators notably nonperforming financing (NPF) and operating expense ratio (OER) have increased during that period.

Table 1: Islamic and Conventional Banks' Financial Indicators

\begin{tabular}{lrrrr}
\hline Ratio & \multicolumn{1}{c}{$\mathbf{2 0 1 2}$} & \multicolumn{1}{l}{$\mathbf{2 0 1 3}$} & \multicolumn{1}{l}{$\mathbf{2 0 1 4}$} & \multicolumn{1}{c}{$\left.\mathbf{2 0 1 5}^{*}\right)$} \\
\hline CAR & $14.13 \%$ & $14.42 \%$ & $15.74 \%$ & $14.09 \%$ \\
& $(17.43 \%)$ & $(18.13 \%)$ & $(19.57 \%)$ & $(20.28 \%)$ \\
ROA & $2.14 \%$ & $2.00 \%$ & $0.79 \%$ & $0.89 \%$ \\
& $(3.11 \%)$ & $(3.08 \%)$ & $(2.85 \%)$ & $(2.29 \%)$ \\
ROE & $24.06 \%$ & $17.24 \%$ & $5.85 \%$ & $7.98 \%$ \\
NPF & $2.22 \%$ & $2.62 \%$ & $4.33 \%$ & $4.73 \%$ \\
FDR & $100.00 \%$ & $100.32 \%$ & $91.50 \%$ & $96.52 \%$ \\
& $(83.58 \%)$ & $(89.70 \%)$ & $(89.42 \%)$ & $(88.46 \%)$ \\
OER & $74.97 \%$ & $78.21 \%$ & $94.16 \%$ & $94.22 \%$ \\
& $(74.10 \%)$ & $(74.08 \%)$ & $(76.29 \%)$ & $(81.40 \%)$ \\
\hline
\end{tabular}

Note: *) Per June 2015, figures in the bracket are conventional banks' indicators.

OER stands for operating expense ratio.

Source: Islamic Banking Statistics and Indonesian Banking Statistics (OJK). 
From the table above, we can find that the performance of conventional banks is better than that of Islamic banks. In other words, in terms of quality of capital, profitability, quality of financing and efficiency, conventional banks in the country outperformed Islamic banks. Yet, the idea that the Islamic banking system is superior to the conventional one, which seems does not fit the reality in Indonesian financial market.

Table 1 indicates that Islamic banks are underperformed. It is indicated by a $25.7 \%$ increase in OER of Islamic banks. Moreover, the OER of Islamic banks is higher than conventional banks during the period of 2012 2015. In view of this, Islamic banks relatively have spent more on operating costs. Another notable aspect of the table is about the financing quality of Islamic banks. The non-performing financing (NPF) of Islamic banking industry unfortunately has increased more than double from $2.22 \%$ in 2012 to $4.73 \%$ in 2015 . The fact that NPF has increased for more than $100 \%$ and greater than the banking industry average is alarming to the stakeholders of Islamic banking industry and general public ${ }^{1}$. Nevertheless, it could erode the soundness of Islamic banking system which eventually may shake the public confidence on the industry.

The concept of efficiency basically lies on a mechanism done by a business organisation that produces outputs from a given level of inputs. Moreover, in the market we can find any firm that dominates and leads the industry. In this regard, the firm is kind of a benchmark that can be set as a good example by other competing firms. In other words, the way the dominance firm lead the industry can be regarded as best practice that set a role model for other firms.

In the literature about productivity and efficiency this best practice of firms in the industry is known as "frontier" (Fried, Lovell, \& Schmidt, n.d.). Furthermore, the frontier is deemed as the best thing that a firm in the industry can achieve and it is labelled as "efficient". Meanwhile, other firms that perform lower than or could not reach the frontier are regarded as "inefficient" (Fried et al., n.d.).

According to Sherman and Zhu (n.d.), efficiency is a ratio of output over input. Given a same level of inputs, greater outputs produced are much more desirable. In other words, greater output-input ratio means greater efficiency level (Sherman \& Zhu, n.d.). Another benefit of the efficiency approach is it allows direct comparison amongst organisations on how efficient they utilise limited resources (Jacobs, 2000).

Measuring organisational performance using efficiency approach can be found in a number of previous empirical studies. It has been applied in a number of settings notably hospital (Atilgan, 2016; Jacobs, 2000), banks (Ali, Saiti, Hamzah, Razak, \& Ariff, 2015; Saaid, Rosly, Ibrahim, \& Abdullah, 2003; Sufian \& Habibullah, 2009), schools and many more ${ }^{2}$. To measure efficiency of organisations, prior studies normally employ the data envelopment analysis (DEA) and the stochastic frontier analysis (SFA).

The significant rise in operating costs (BOPO) and NPL suggests inherent problems within the Islamic banking industry. Moreover it can be said, compared to conventional banks, Islamic banks are less efficient in managing their operational activities. Resti (1997) suggests heighten competition and pressure in the banking industry has jeopardised the efficiency of commercial banks. Owing to this argument, there is a need to analyse the performance of Islamic banks particularly from the efficiency perspective.

The concept of efficiency of business organisations can be found in the microeconomics literature. It is basically derived from the neoclassical theory of production (Matthews \& Thompson, 2008). The theory suggests that cost efficiency is a product of technical efficiency and allocative efficiency. Moreover the efficiency concept can be explained using the curve below. Resti (1997) explains that efficiency simply means a firm that produces more outputs using the same level of inputs or reducing the level of inputs while maintaining the same level of outputs.

From the curve below we can see that a firm can reach an efficient cost-minimizing position (economic efficiency) when the isoquant touches or equal to the isocost line (at the point $e)^{3}$. Moreover, a firm can produce at a $100 \%$ technically efficient condition if its position is along the isoquant line (point a). This notion of technical efficiency thus suggests that when a firm at the point $c$ means that it does not $100 \%$ technically efficient in production activities. Furthermore, a firm is regarded in an allocative efficiency position if it moves from point a to point $e$ (efficient cost-minimizing position) (Matthews \& Thompson, 2008) ${ }^{4}$. Fried et al., (n.d.) explain that in the case of airline industry, technical (in)efficiency is related to waste resource given the amount of traffic. Meanwhile, the allocative (in)efficiency is related to incorrect combination of resources, given their prices.

One of the approaches that can be used to measure the efficiency level of business organizations is data envelopment analysis (DEA). This method was initially introduced by Charnes, Cooper and Rodes (Sale \& Sale, 2002). It is a non-parametric approach to measure efficiency particularly to find frontier estimation (Coelli, 1996).

\footnotetext{
${ }^{1}$ According to OJK, NPL of conventional banks is around $2.9-3.1 \%$ in the first quarter of 2016 .

${ }^{2}$ For a rich list of numerous studies that employ the efficiency approach, interested readers can refer to Fried et al. (n.d.)

${ }^{3}$ Isocost line is a curve that depicts all combinations of production factors namely labour and capital for a given level of total cost. Meanwhile isoquant shows all combinations of production factors to produce a given amount of output (Case \& Fair, 1999). Allocative efficiency is a product of cost efficiency (CE) divided by technical efficiency (Matthews \& Thompson, 2008)

${ }^{4}$ The move of isocost line to the right side means higher inputs price (Baye, 2009)
} 
Additionally, Sale and Sale, (2002) suggests researchers need to consider a few of critical things prior using the DEA model namely proper definition of DMU's, inputs and outputs.

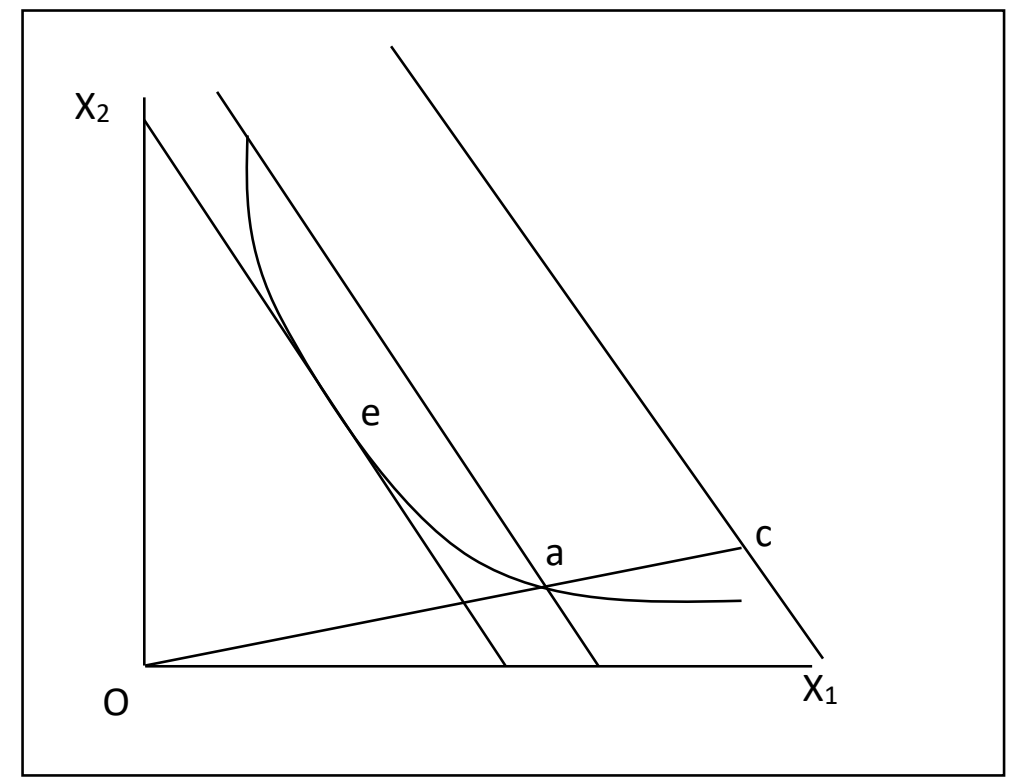

Source: Adapted from Matthews and Thompson (2008)

Figure 1. Technical Efficiency and Allocative Efficiency

The description of the DEA model can be explained by assuming data on $\mathrm{K}$ inputs and $\mathrm{M}$ outputs on each of $\mathrm{N}$ firms ${ }^{5}$. Under the assumption of Constant Return to Scale (CRS), DEA can be calculated in the form of ratio. Moreover, we need to compute the ratio of each firm or decision-making unit (DMU). The ratio is a product of whole outputs divided by all inputs.

However, the CRS assumption can only be met if all firms are operating at optimal scale (Coelli, 1996). Moreover, he suggests that this condition is difficult to achieve particularly in imperfect competition environment and when DMU's face a number of constraints. Owing to this limitation, the variable return to scale (VRS) assumption is more appropriate in such circumstances.

The DEA approach has been employed in numerous previous studies. It is applied in efficiency measurement studies particularly in the context of hospital (Jacobs, 2000), commercial banks (Ismail, Abd. Majid, \& Ab. Rahim, 2013; Resti, 1997; Sufian \& Habibullah, 2009; Tortosa-Ausina, 2003) housing companies (Veenstra, Koolma, \& Allers, 2016), and insurance companies (Cummins, Weiss, Xie, \& Zi, 2010). Given the DEA is widely used in different context, we can say that the approach is more appealing due to its practicality ${ }^{6}$.

The empirical work of Resti (1997) analyse the cost-efficiency of Italian banks during the period of 19881992. The study employs parametric and non-parametric approaches for efficiency. It uses loans, deposits, and non-interest income as output factors. Moreover, for the input factors it uses labour and capital. Additionally the price of labour and the price of capital are used as the weight in the DEA model. The study finds that there are wide gaps between the most efficient banks and the least ones. Moreover, the geographical effect has significantly impacted the efficiency scores of Italian banks.

The study of Tortosa-Ausina (2003) investigates the link between nontraditional activities and bank efficiency in the Spanish banking industry especialy in the period of 1986-1997. Similar to the work of Resti (1997), it employs both parametric and non-parametric approaches to efficiency. However, it differs from Resti (1997) particularly in using deposits as input factor. The study corroborates the notion that nontraditional activities contribute to bank efficiency. However, it argues that the size and time effects influence the variation of the efficiency score.

Sufian and Habibullah (2009) investigates the efficiency of commercial in ASEAN-4 countries notably Malaysia, Thailand, Indonesia and Philippines. The DEA approach was employed to measure the efficiency of commercial banks over the period 1999-2005. Moreover, the study tries to investigae the linkage amongst banks' efficiency score, bank-specific variables and macroeconomics variables. The findings of the study suggest that

\footnotetext{
${ }^{5}$ This part is adapted from Coelli (1996).

${ }^{6}$ Despite its applicability in many different settings, this section is intended to review extant literature of DEA that has been used in the banking industry
} 
bank efficiency has positive relationship with the level of equity. In other words, banks with more equity capital are more efficient. Meanwhile, it also finds a negative relationship between non-interest income and efficiency. In view of this, it contradicts to the findings of Tortosa-Ausina (2003) which suggests a positive linkage between nontraditional activities and banks efficiency.

Ismail et al. (2013) analyses the efficiency of Islamic and conventional banks in Malaysia over the period 2006-2009. The study uses the DEA approach to measure the efficiency particularly using five types of efficiency namely cost efficiency, scale efficiency, technical efficiency, allocative efficiency and pure technical efficiency. The study finds that in the case of conventional (Islamic) banks the technical efficiency contributes more (less) to cost efficiency than allocative efficiency.

\section{Research Method}

The present study uses secondary data which will be collected from the financial reports of Islamic banks. Two main channels are targeted to obtain the data set namely the website of each Islamic bank and the database of Islamic banks financial reports provided by OJK in its website. Population of the study is all Islamic commercial banks in Indonesian. In this regard, we will include Islamic banks which operate as a separate entity. With that in mind, Islamic banks' windows or known as special Islamic banking unit within conventional bank and Islamic rural banks are not included in the sample of present study. Additionally, other criteria of the sample are the banks should have operated in the year of observation namely 2014-2015. Finally, the banks should have the inputs and the outputs in positive and non-zero figure.

To measure the efficiency of DMU, we can use the ratio of outputs over inputs $u^{\prime} y_{i} / v^{\prime} x_{i .}$. To find the weight, we need to derive the following linear programming:

$$
\begin{array}{ll}
\max _{\mathrm{u}, \mathrm{v}} & \left(\mathrm{u}^{\prime} \mathrm{y}_{\mathrm{i}} / \mathrm{v}^{\prime} \mathrm{x}_{\mathrm{i}}\right) \\
\text { st } & \mathrm{u}^{\prime} \mathrm{y}_{\mathrm{j}} / \mathrm{v}^{\prime} \mathrm{x}_{\mathrm{j}} \leq 1, \\
\mathrm{u}, \mathrm{v} \geq 0 &
\end{array}
$$

However the above formulation contains problem of infinite solution. To avoid the problem, we need to impose the constraint of $\mathrm{v}^{\prime} \mathrm{x}_{1}=1$, which provides:

$$
\begin{aligned}
& \max _{\mu, \mathrm{v}} \quad\left(\mu y_{i}\right) \\
& \text { st } \quad v^{\prime} x_{i}=1, \\
& \mu y_{i}-v^{\prime} x_{i}=1 \\
& \mu, v \geq 0
\end{aligned}
$$

Linear programming can be used to derive an equivalent envelopment form of this problem

$$
\begin{aligned}
& \min _{\theta, \mathrm{v}} \quad \theta \\
& \text { st } \quad-\mathrm{y}_{\mathrm{i}}+\mathrm{Y} \lambda \geq 0, \\
& \theta \mathrm{x}_{\mathrm{i}}-\mathrm{X} \lambda \geq 0 \\
& \lambda \geq 0
\end{aligned}
$$

The efficiency score for the i-th DMU is from the $\theta$ obtained.

To measure efficiency under the DEA framework, we need to specify a set of inputs and outputs. Different types of business organizations might need different set inputs and outputs. In the context of commercial bank efficiency measurement, problem arise when deposits are regarded as inputs (intermediation approach) as well as outputs (value added approach) (Resti, 1997). Ismail et al. (2013), however argues using the intermediation approach in DEA is more appropriate in the context of Islamic banks efficiency. The study of Sufian and Habibullah (2009), however uses not only intermediation but also revenue approach for commercial bank study.

Table 2: Operational Definition of Variable

\begin{tabular}{cll}
\hline Variable & \multicolumn{1}{c}{ Variable name } & \multicolumn{1}{c}{ Definition } \\
\hline $\mathrm{Y}_{1}$ & Traditional income & Income generated from financing activities \\
$\mathrm{Y}_{2}$ & Non-traditional income & Income generated from fee-based activities \\
$\mathrm{X}_{1}$ & Traditional expenses & Cost on customer deposits \\
$\mathrm{X}_{2}$ & Nontraditional expense & Cost on other source of funds and personnel expenses \\
\hline
\end{tabular}


The present study adopts the profit-oriented (revenue) approach in which use revenues as outputs and expenses as inputs (Drake, Hall, \& Simper, 2005). Moreover, as suggested by Sufian and Habibullah (2009), under the revenue approach, traditional income $\left(\mathrm{Y}_{1}\right)$ and non-traditional $\left(\mathrm{Y}_{2}\right)$ are classified as outputs. Meanwhile, traditional expense $\left(\mathrm{X}_{1}\right)$ and non-traditional expense are regarded as inputs.

The data in the form of inputs and outputs will be analysed using the DEA approach. Under this framework, the DMU is considered as efficient if its efficiency score is equal to one and it is not efficient if the efficiency score less than one. The efficiency measure would be divided into technical efficiency (TE), pure technical efficiency (PTE) and scale efficiency (SE). TE basically is the product of PTE times SE. Meanwhile, PTE is related to managerial efficiency and SE is related to size of operation efficiency (Aghimien, Kamarudin, Hamid, \& Noordin, 2016). Decomposing TE into SE and PTE can help to find source of inefficiency (Avkiran, 1999). Moreover, as suggested by Sufian and Habibullah (2009), input-oriented, variable return to scale (VRS) would be employed in DEA model.

This study only observing Islamic commercial banks. In view of this, Islamic bank windows and Islamic rural banks are excluded from the sample size, As a result, there are twelve full-fledge Islamic commercial banks namely BCA Syariah, BSM, BMI, BRI Syariah, Panin Syariah, Mega Syariah, BJB Syariah, Bukopin Syariah, Maybank Syariah, BNI Syariah, BTPN Syariah, Victoria Syariah. Moreover, data were collected from annual report of Islamic banks for the year of 2014-2015 and all numerical data are recorded in Indonesian Rupiah (IDR).

Table 3. Total assets of Islamic commercial banks in 2015

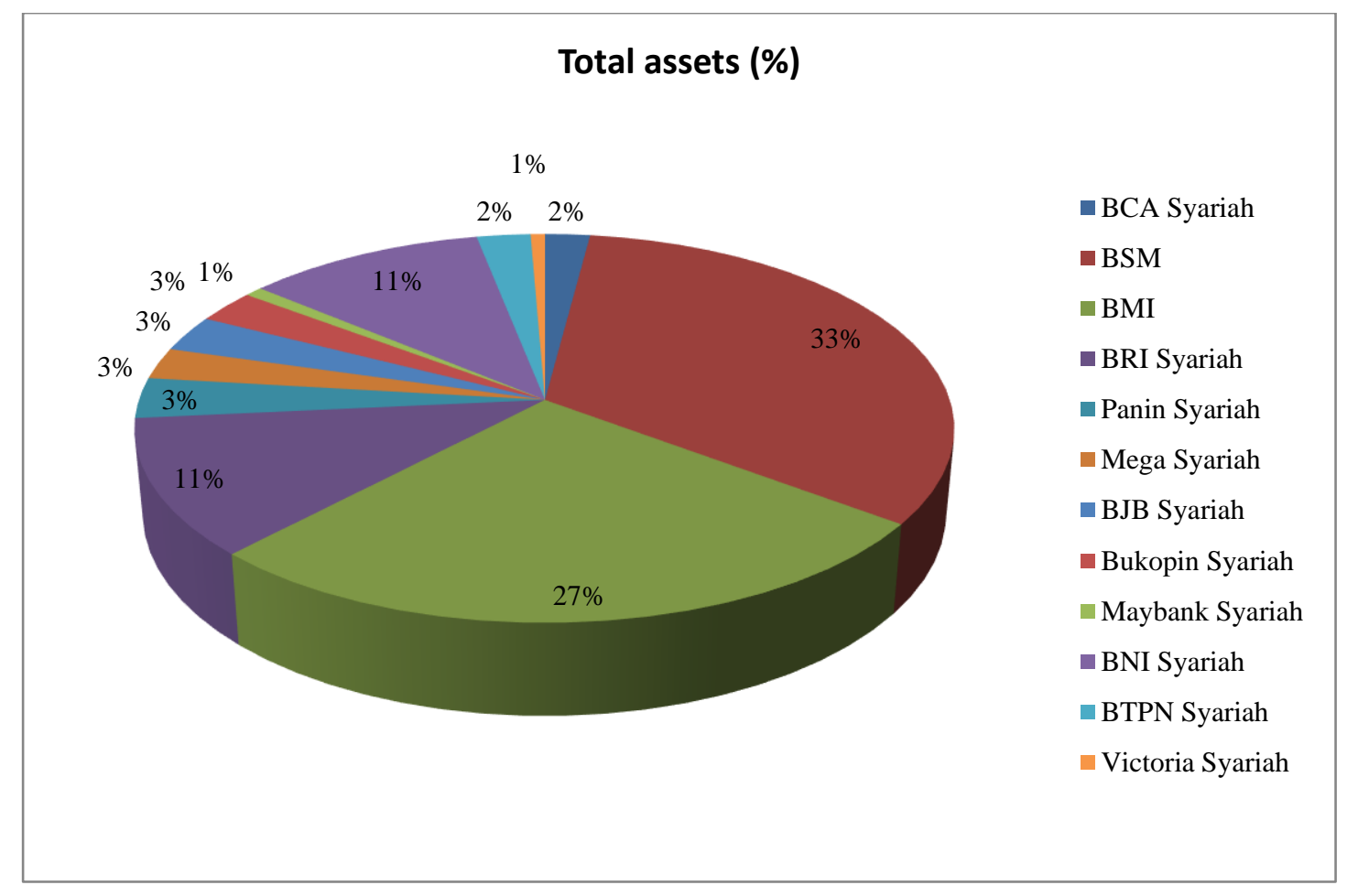

In terms of size, Bank Syariah Mandiri (BSM) secures the first position with total assets of 70.4 trillion IDR which is equivalent to 33 percent of total assets of all Islamic commercial banks in Indonesia. BSM is a state-owned bank and it is a subsidiary of the biggest bank in the country namely Bank Mandiri. In the second position is Bank Muamalat Indonesia (BMI) with total assets equal to 57.2 trillion IDR (27 percent). BMI is the oldest Islamic commercial bank in Indonesia which was incepted in 1991. Currently, BMI is owned by a number of international institutions with the three largest shareholders are Islamic Development Bank (IDB), National Bank of Kuwait Group and Saudi Economic and Development Company (SEDCO). Meanwhile, in the lowest position is Bank Victoria Syariah with total assets of 1.3 trillion IDR (0.65 percent). Bank Victoria Syariah initially started as a conventional bank in 1967. After 40 years in operation, its proposal of conversion into Islamic commercial bank was approved by Central Bank of Indonesia in 2007. Effectively, it began its operation as Islamic bank in 2010. 
Table 4: Descriptive statistic of inputs and outputs for DEA (in billion IDR)

\begin{tabular}{rlrrrr}
\hline \multirow{2}{*}{ Year } & $\begin{array}{c}\text { Descriptive } \\
\text { statistic }\end{array}$ & $\begin{array}{c}\text { Traditional } \\
\text { income (Y1) }\end{array}$ & $\begin{array}{c}\text { Non-traditional } \\
\text { income (Y2) }\end{array}$ & $\begin{array}{c}\text { Traditional } \\
\text { expenses (X1) }\end{array}$ & $\begin{array}{c}\text { Non-traditional } \\
\text { expenses (X2) }\end{array}$ \\
\hline \multirow{2}{*}{2014} & Mean & 1623.20 & 167.35 & 752.76 & 886.09 \\
& SD & 1858.02 & 284.40 & 1070.13 & 1134.60 \\
& Min & 148.88 & 1.77 & 17.27 & 58.24 \\
& Max & 5487.19 & 1017.69 & 3379.84 & 4012.68 \\
\hline \multirow{2}{*}{2015} & Mean & 1761.21 & 206.15 & 821.68 & 1004.08 \\
& SD & 1902.18 & 296.11 & 929.04 & 1146.42 \\
& Min & 144.37 & 1.23 & 38.32 & 61.48 \\
& Max & 5960.02 & 955.65 & 2873.57 & 4035.15 \\
\hline
\end{tabular}

The descriptive statistic can be seen in table 4.The data were extracted from Islamic banks' financial reports particularly for the period of 2014-2015. As we can observe in the above table, on average the four variables increase in value during the period of observation. Increased revenues might contribute to better profitability; however increased costs can cancel out the revenues contribution to banks' earnings. In view of this, the situation presents dilemma to Islamic banks. That is to say, they are able to boost revenues at the expense of greater costs. It seems that Islamic banks in Indonesia might experience inefficiency problem.

\section{Efficiency of Islamic Banks}

Table 5: Efficiency score of Islamic Banks for 2014

\begin{tabular}{lcccc}
\hline \multicolumn{1}{c}{ DMU } & TE & PTE & SE & RTS \\
\hline BCA Syariah & 0.716 & 0.806 & 0.888 & IRS \\
BSM & 1.000 & 1.000 & 1.000 & ORS \\
BMI & 0.736 & 1.000 & 0.736 & DRS \\
BRI Syariah & 1.000 & 1.000 & 1.000 & ORS \\
Panin Syariah & 1.000 & 1.000 & 1.000 & ORS \\
Mega Syariah & 0.955 & 0.957 & 0.998 & IRS \\
BJB Syariah & 1.000 & 1.000 & 1.000 & ORS \\
Bukopin Syariah & 0.899 & 0.933 & 0.964 & IRS \\
Maybank Syariah & 1.000 & 1.000 & 1.000 & ORS \\
BNI Syariah & 0.662 & 0.818 & 0.809 & DRS \\
BTPN Syariah & 0.594 & 0.661 & 0.899 & DRS \\
Victoria Syariah & 0.556 & 0.811 & 0.686 & IRS \\
Average & $\mathbf{0 . 8 4 3}$ & $\mathbf{0 . 9 1 5}$ & $\mathbf{0 . 9 1 5}$ & \\
\hline DMU = decision-making unit, TE = technical efficiency, PTE = pure technical \\
efficiency, SE = scale efficiency, RTS = return to scale, IRS = increasing return \\
to scale, DRS = decreasing return to scale, ORS = optimum return to scale
\end{tabular}

The DEA input-oriented model finds, on average, Islamic commercial banks in Indonesia earn TE score of 0.843 , while PTE and SE both equal to 0.915 particularly for the year 2014. The results suggest that Islamic banks in Indonesia could have maintained the same level of productivity with a reduction of inputs around 15.7 percent. In other words, Islamic banks could have managed to produce the current level of outputs using only 84.3 percent of the inputs. Additionally, the present study finds that both pure technical inefficiency and scale inefficiency share the same impact on technical efficiency of Islamic banks.

With regards to individual bank's efficiency score, five banks namely BSM, BRI Syariah, Panin Syariah, BJB Syariah and Maybank Syariah get efficiency score equal to one in 2014. These four banks can be said as have operated in efficiency frontier of CRS. In view of this, efficient Islamic banks could have produced a proportionate increase in outputs along with an increase in inputs. Furthermore, other banks fall into either decreasing return to scale (DRS) or increasing return to scale (IRS). We find four banks namely BCA Syariah, Mega Syariah, Bukopin Syariah and Victoria Syariah are in increasing return to scale (IRS). This suggests, an increase in inputs can lead a greater (disproportionate) increase in outputs particularly for banks in IRS. Moreover, another three banks are under category of decreasing return to scale (DRS) namely BMI, BNI Syariah and BTPN Syariah. Unlike IRS, in DRS, a rise in inputs can lead to a lower percentage increase in outputs.

Moreover, in 2015, five banks namely Panin Syariah, Mega Syariah, Bukopin Syariah Maybank Syariah and BTPN Syariah reach efficiency score equal to one or have operated in efficiency frontier. Surprisingly none of the top four Islamic banks by the size namely BSM, BMI, BRI Syariah and BNI Syariah are placed in this 
category. Furthermore, Panin Syariah as the only publicly listed Islamic bank in Indonesia maintains its efficiency performance for two consecutive years notably 2014-2015. Meanwhile, Bukopin Syariah and Mega Syariah have improved their productivity from 2014's performance. Overall, there has been lower efficiency performance of Islamic banks with technical efficiency score is 0.832 . Unlike the condition of 2015 in which pure technical inefficiency and scale inefficiency share the same impact on technical efficiency, in 2015, the technical inefficiency is mainly attributed to scale inefficiency $(0.114)$ rather than pure technical inefficiency $(0.065)$.

Table 6: Efficiency score of Islamic Banks for 2015

\begin{tabular}{lcccc}
\hline \multicolumn{1}{c}{ DMU } & TE & PTE & SE & RTS \\
\hline BCA Syariah & 0.765 & 0.818 & 0.936 & DRS \\
BSM & 0.756 & 1.000 & 0.756 & DRS \\
BMI & 0.787 & 1.000 & 0.787 & DRS \\
BRI Syariah & 0.681 & 0.865 & 0.787 & DRS \\
Panin Syariah & 1.000 & 1.000 & 1.000 & ORS \\
Mega Syariah & 1.000 & 1.000 & 1.000 & ORS \\
BJB Syariah & 0.640 & 0.711 & 0.899 & DRS \\
Bukopin Syariah & 1.000 & 1.000 & 1.000 & ORS \\
Maybank Syariah & 1.000 & 1.000 & 1.000 & ORS \\
BNI Syariah & 0.783 & 1.000 & 0.783 & DRS \\
BTPN Syariah & 1.000 & 1.000 & 1.000 & ORS \\
Victoria Syariah & 0.567 & 0.828 & 0.685 & IRS \\
Average & $\mathbf{0 . 8 3 2}$ & $\mathbf{0 . 9 3 5}$ & $\mathbf{0 . 8 8 6}$ & \\
\hline DMU &
\end{tabular}

DMU = decision-making unit, TE = technical efficiency, PTE = pure technical efficiency, $\mathrm{SE}=$ scale efficiency, $\mathrm{RTS}=$ return to scale, IRS $=$ increasing return to scale, DRS $=$ decreasing return to scale, ORS = optimum return to scale

Meanwhile, BSM and BRI Syariah that reach maximum efficiency score previously, in 2015 have to be downgraded to decreasing return to scale. In table 4.4, it can be observed that BSM undergoes scale inefficiency, while BRI suffers both pure technical and scale inefficiency. In view of this, the technical inefficiency of BSM is mainly attributed to scale of operation. In other words, BSM is unable to exploit its size of operation to produce more outputs. That is, as the biggest Islamic bank in the country, BSM should have been more productive than other contenders in the industry. In the case of BRI Syariah, the technical inefficiency is mainly contributed by the scale inefficiency rather than pure technical efficiency. Unlike the situation faced by BSM, the inefficiency of BRI is more attributed to managerial incompetency to manage bank's resources gaining more potential outputs.

Table 7: Return to Scale of Islamic Banks (2014-2015)

\begin{tabular}{lll}
\hline \multicolumn{1}{c}{ DMU } & $\mathbf{2 0 1 4}$ & $\mathbf{2 0 1 5}$ \\
\hline BCA Syariah & IRS & DRS \\
BSM & ORS & DRS \\
BMI & DRS & DRS \\
BRI Syariah & ORS & DRS \\
Panin Syariah & ORS & ORS \\
Mega Syariah & IRS & ORS \\
BJB Syariah & ORS & DRS \\
Bukopin Syariah & IRS & ORS \\
Maybank Syariah & ORS & ORS \\
BNI Syariah & DRS & DRS \\
BTPN Syariah & DRS & ORS \\
Victoria Syariah & IRS & IRS \\
\hline
\end{tabular}

Special attention needs to be given to Bank Victoria Syariah which always gets the lowest technical efficiency score for two years. In its annual report we find the bank has undergone a difficult situation during the period of study (2014-2015). A number of indicators exhibit negative figures notably ROA and ROE. Other indicators namely total financing given, customers deposits, level of equity have been declining. Moreover, its non-performing financing (NPF) is getting worse which reached 9.80 percent (in 2015) compared to 7.10 percent (in 2014). However, its liquidity position is relatively sufficient to meet the short-term liabilities. It is a dilemma when a company maintains sufficient liquidity position at the expense of low profitability. 
The period of 2014-2015 is a challenging episode for banking industry in the country. Economic slowdown, global market pressure and heighten competition in financial market have negatively impacted conventional as well as Islamic commercial banks. In view of this, the low performance of Bank Victoria Syariah could have been contributed partially by a worsening systematic risk in the country.

\section{Conclusion}

The present study investigates the efficiency of Islamic banks in Indonesia particularly for the period of 20142015. To meet that objective, the data envelopment analysis (DEA) particularly input-oriented, variable return to scale (VRS) has been employed. Additionally, twelve full-fledge Islamic commercial banks are included as the sample of the study.

Having analysed using the DEA model, we find the average technical efficiency score of Islamic banks in 2014 is 0.843 . In this regard, the inefficiency of Islamic banks is attributed equally to pure technical efficiency and scale efficiency. Moreover, the average technical efficiency score of Islamic banks for the year of 2015 is 0.832 which is lower than the previous year. The inefficiency of Islamic banks in 2015 is mainly contributed by the scale inefficiency. Moreover, the results suggest a declining of Islamic banks productivity during the period of study.

The last few years have been turned into a difficult period for banking industry in general and Islamic banking sector in particular. Macroeconomic and structural problems have deteriorated Islamic banks financial performance. According to the latest report of the Indonesia inancial services authority (OJK), Islamic banks low performance is the result of increasing costs, higher non-performing financing and lack of competitive advantages. With that in mind, there are more efforts need to be done by the stakeholders to ensure the Islamic banking sector can survive this challenging circumstance.

The findings of the present study confirm the report of OJK that suggests Islamic banks in Indonesia have experienced a declining pattern. A number of key performance indicators indicated that Islamic banks suffer low performance more than their conventional peers. The problem of inefficiency notably high costs and increased non-performing financing has contributed to the below-average performance of Islamic banking sector.

Despite the strong desire to surpass the five percent market share threshold, there are a number of essential strategies need to done to ensure Islamic banking sector can sustain in the future. Given Islamic banks are smaller compared to conventional banks, regulator and stakeholders need to encourage for merger and acquisition in Islamic banking sector. From our opinion big-sized Islamic bank has the advantage of the capacity to implement a universal banking model which could potentially earn diversification gains, economies of scale and economies of scope. In view of this, Islamic banking sector can elevate its current position in financial market. Another improvement that needs to be implemented is an advanced technology adoption. By using hi-tech computerized system Islamic banks might able to minimize costs, deliver fast and reliable financial services to the customers.

For future study, research can be directed to monitor the efficiency of Islamic banking sector after the implementation of ASEAN Economic Community (AEC) and ASEAN Banking Integration Framework (ABIF) in the region. In this new era, barriers to international trade are minimized and host country has to open its border to foreign companies from neighbouring countries. We expect that competition will be getting intensified particularly in banking industry.

\section{References}

Aghimien, P. A., Kamarudin, F., Hamid, M., \& Noordin, B. (2016). Efficiency of gulf cooperation council banks: empirical evidence using data envelopment analysis. Review of International Business, 26(1), 118-136. http://doi.org/10.1108/RIBS-11-2013-0111

Ali, F., Saiti, B., Hamzah, S., Razak, A., \& Ariff, M. (2015). The impact of efficiency on discretionary loans / finance loss provision : A comparative study of Islamic and conventional banks. Borsa Istanbul Review, 15(4), 272-282. http://doi.org/10.1016/j.bir.2015.06.002

Atilgan, E. (2016). Stochastic frontier analysis of hospital efficiency : does the model specification matter. Journal of Business, Economics and Finance, 5(1). http://doi.org/10.17261/Pressacademia.2016116550

Avkiran, N. K. (1999). An application reference for data envelopment analysis in branch banking: helping the novice researcher. International Journal of Bank Marketing, 17(5), 206-220.

Baye, M. R. (2009). Managerial Economics and Business Strategy (Internatio). New York: McGraw-Hill/Irwin.

Case, K. E., \& Fair, R. C. (1999). Principle of Economics (5th ed.). New Jersey: Prentice-Hall, Inc.

Coelli, T. J. (1996). A Guide to DEAP Version 2.1: A Data Envelopment Analysis (Computer) Program (8/96). 
Cummins, J. D., Weiss, M. a., Xie, X., \& Zi, H. (2010). Economies of scope in financial services: a DEA efficiency analysis of the US insurance industry. Journal of Banking and Finance, 34(7), 1525-1539. http://doi.org/10.1016/j.jbankfin.2010.02.025

Drake, L. M., Hall, M. J. B., \& Simper, R. (2005). The impact of macroeconomic and regulatory factors on bank efficiency: a non-parametric analysis of Hong Kong's banking system (No. 1/2015). Hong Kong. http://www.hkimr.org/uploads/publication/237/ub_full_0_2_100_wp200501_text.pdf

Fried, H. O., Lovell, C. A. K., \& Schmidt, S. S. (n.d.). Efficiency and Productivity. http://pages.stern.nyu.edu/ wgreene/FrontierModeling/SurveyPapers/Lovell-Fried-Schmidt.pdf

Ismail, F., Abd. Majid, M. S., \& Ab. Rahim, R. (2013). Efficiency of Islamic and conventional commercial banks in Malaysia. Journal of Financial Reporting and Accounting, 11, 92-107. Retrieved from bstract

Jacobs, R. (2000). Alternative Methods to Examine Hospital Efficiency: Data Envelopment Analysis and Stochastic Frontier Analysis (No. DP177). https://www.york.ac.uk/che/pdf/DP177.pdf

Matthews, K., \& Thompson, J. (2008). The economics of banking. John Wiley \& Sons Ltd.

Resti, A. (1997). Evaluating the cost-efficiency of the Italian banking system: What can be learned from the joint application of parametric and non-parametric techniques. Journal of Banking \& Finance, 21(2), 221-250. http://doi.org/10.1016/S0378-4266(96)00036-2

Saaid, A. elrhman E., Rosly, S. A., Ibrahim, M. H., \& Abdullah, N. (2003). The X-efficiency of the Sudanese Islamic banks. IIUM Journal of Economics and Management, 11, 123-141.

Sale, R. S., \& Sale, M. L. (2002). Data Envelopment Analysis : A Primer for Novice Users and Students at all Levels. https://pdfs.semanticscholar.org/6632/91bc8fab71336f0707f870246789a1fa462d.pdf

Sherman, \& Zhu. (n.d.). Data envelopment analysis explained. https://link.springer.com/chapter/10.1007/0-38733231-6_2

Sufian, F., \& Habibullah, M. S. (2009). The ASEAN-4 banking sectors. Bullettin of Monetary Economics and Banking, 12(2), 121-149.

Tortosa-Ausina, E. (2003). Nontraditional activities and bank efficiency revisited: a distributional analysis for Spanish financial institutions. Journal of Economics and Business, 55(4), 371-395. http://doi.org/10.1016/S0148-6195(03)00026-2

Veenstra, J., Koolma, H. M., \& Allers, M. A. (2016). Scale,mergers and efficiency : the case of Dutch housing corporations. Journal of Housing and the Built Environment, (May). http://doi.org/10.1007/s10901-0169515-4 